6 - ORIGINAL ARTICLE

ALIMENTARY TRACT

\title{
Oxidative stress and fatty acid profile in Wistar rats subjected to acute food restriction and refeeding with high-fat diets ${ }^{1}$
}

\author{
Ana Lígia da Silva Nassar ${ }^{\mathrm{I}}$, Luisa Pereira Marot', Paula Payão Ovidio ${ }^{\mathrm{II}}$, Gabriela Salim Ferreira de Castro ${ }^{\mathrm{III}}$, Alceu Afonso \\ Jordão Júnior ${ }^{\mathrm{IV}}$ \\ INutritionist, Department of Internal Medicine, Faculty of Medicine of Ribeirao Preto-University of Sao Paulo (FMRP-USP), Ribeirao Preto-SP, \\ Brazil. Technical procedures, acquisition and interpretation of data, manuscript writing. \\ ${ }^{I I}$ Master, Laboratory of Nutrition and Metabolism, Department of Internal Medicine, FMRP-USP, Ribeirao Preto-SP, Brazil. Technical procedures, \\ acquisition and interpretation of data. \\ IIIFellow PhD degree, Postgraduate Program in Internal Medicine, Biomedical Investigation, Department of Internal Medicine, FMRP-USP, Ribeirao \\ Preto-SP, Brazil. Technical procedures, acquisition and interpretation of data, statistical analysis, manuscript writing. \\ ${ }^{\text {IV }} \mathrm{PhD}$, Department of Internal Medicine, FMRP-USP, Ribeirao Preto-SP, Brazil. Design the protocol, manuscript writing, supervised all phases of the \\ study, critical revision.
}

\begin{abstract}
PURPOSE: To assess oxidative stress and the profile of fatty acids incorporated into the hepatic tissue of animals refed with high-fat (HF) diets after acute food restriction.

METHODS: Fifty male Wistar rats were divided into five groups and fasting for 48 hours. One group was sacrificed without refeeding (NR), a control group (C) was refed with the standard AIN-93 diet and the remaining groups with HF diets respectively consisting of hydrogenated vegetable oil (PHVO), trans-free (TF) margarine and trans-free margarine enriched with $\omega-3$ and $\omega-6(\mathrm{O})$. After this period the animals were sacrificed for malondialdehyde (MDA), catalase and hepatic fatty acid determination.

RESULTS: The groups refed with HF diets showed elevation of MDA levels compared to the $\mathrm{C}$ group ( $\mathrm{p}<0.001$ for GVH and $\mathrm{p}<0.01$ for TF and $\mathrm{O}$ ). Hepatic catalase activity was higher in the TF and $\mathrm{O}$ groups compared to group $\mathrm{C}$ ( $\mathrm{p}<0.05$ for both). The amount of saturated fatty acids was lower in the PHVO and O groups compared to the remaining ones $(\mathrm{p}<0.001)$.
\end{abstract}

CONCLUSION: The consumption of high-fat diets after prolonged fasting favors oxidative imbalance in hepatic tissue.

Key words: Fasting. Diet, High-Fat, Oxidative Stress. Fatty Acids. Rats. 


\section{Introduction}

Nonalcoholic fatty liver disease (NAFLD) is caused by the accumulation of fat in the hepatocytes, also called steatosis, and is a common cause of chronic liver disease ${ }^{1}$. The incidence of NAFLD is associated with conditions of insulin resistance such as obesity, type 2 diabetes, dyslipidemia and metabolic syndrome, and the disease can progress to inflammation of hepatic tissue called nonalcoholic steatohepatitis (NASH), fibrosis and cirrhosis ${ }^{1}$.

The most accepted theory about the development of NASH postulates that progression occurs in two hits, the first being the accumulation of fat in normal hepatocytes due to increased triglyceride mobilization and free fatty acid oxidation ${ }^{2}$. This process is related to the insulin resistance characteristic of individuals with NAFLD, which is provoked by obesity and by excess dietary intake of energy and fats. Hyperinsulinemia favors steatosis by increasing the de novo synthesis and flow of free fatty acids to the liver, by reducing $\beta$-oxidation and provoking increased levels of pro-inflammatory cytokines such as TNF $\alpha$, IL-1 and IL-6. The second hit is marked by the inflammatory response triggered by the cytokines and by the production of free radicals which characterizes the inflammation of hepatic tissue and steatohepatitis. Thus, the greater the accumulation of fat, the greater the oxidative and inflammatory response $\mathrm{e}^{3,4}$.

Fasting is a practice followed by different populations in association with religious and cultural practices and in pathological conditions such as eating disorders ${ }^{5-7}$. In addition, the period of night sleep characterizes a daily situation of fasting. Many adaptations guarantee the maintenance of metabolic homeostasis in fasting and negative energy balance situations, when the preferential source for the generation of energy - glucose - is restricted or completely absent. Mobilization of triacylglycerols from white adipose tissue then occurs, with the release of glycerol and free fatty acids (FFA). Excess FFA mobilization towards the liver may result in their accumulation in the hepatocytes if the capacity for the transport of very low density lipoproteins (VLDL) is exceeded, giving origin to a situation of hepatic steatosis ${ }^{8}$.

The excessive consumption of high-fat diets is strongly associated with metabolic syndrome, insulin resistance and hepatic steatosis and is a central characteristic of the so-called "modern life style",.

Population studies that characterize the eating profile of populations with NAFLD or NASH provided the first evidence of a causal relation between lipid ingestion and the development of this liver disease, indicating that the consumption of saturated fat may cause changes in the metabolism and the development of
NASH by lipo-apoptosis mechanisms ${ }^{10,11}$. In addition, the greater susceptibility of polyunsaturated fatty acids (PFA) to peroxidation by free radicals has led to the investigation of a possible relation between high-fat diets rich in PFA and NASH, since the second step in the development of this liver disease implies the presence of an inflammatory process which is strongly related to the prooxidative environment ${ }^{12}$.

The objective of the present study was to assess the oxidative stress and the profile of fatty acids incorporated into the hepatic tissue of animals refed with high-fat diets after acute food restriction.

\section{Methods}

All animals were handled according to the recommendations of The Guide for the Care and Use of Laboratory Animals ${ }^{13}$ prepared by the National Academy of Sciences and published by the National Institutes of Health (NIH publication 8623 revised 1985), and the experimental procedure was approved by the Animal Research Ethics Committee of FMRP/USP.

Fifty male Wistar rats weighing 250-270 g were used. The animals were from the Animal House of the Ribeirao Preto Campus of USP and were later maintained in the animal facilities of the Department of Internal Medicine, Faculty of Medicine of Ribeirao Preto, USP. The rats were housed in individual cages in an environment with controlled temperature $\left(24 \pm 2^{\circ} \mathrm{C}\right)$ and under a 12 hour light-dark cycle.

The animals were divided at random into five groups and starved for 48 hours. After this period they were refed for 24 hours and then sacrificed. Before the experiment, the animals were allowed to adapt to the environment and to the diet for three days.

All solvents and reagents used for the FA quantification were of chromatography grade and all the other chemicals used were at least of ACS purity. Standards and biochemical reagents were obtained from Sigma Chemical Co. (St. Louis, MO, USA). $\mathrm{H}_{2} \mathrm{O}_{2}$ was purchased from Merck \& Co, Inc. (Sao Paulo-SP, Brazil).

\section{Preparation of the diets}

Five experimental groups of ten0 animals each were set up according to the diet offered during the refeeding period. One group was sacrificed under fasting conditions without refeeding - no refeeding group (NR) and the remaining groups were refed for 24 hours with diet of different compositions: Control group (C) refed with the standard AIN-93 diet ${ }^{14}$; Partially Hydrogenated Vegetable Oil group (PHVO) which received $20 \%$ AIN-93 diet $+80 \%$ partially hydrogenated fat, 
Trans-Free Margarine group (TF) refed with 20\% AIN-93 diet + $80 \%$ trans-free margarine, and group refed with Trans-free Margarine containing mono- and polyunsaturated fats $+20 \%$ AIN-93 diet $+80 \%$ trans-free margarine enriched with mono- and polyunsaturated fats. Table 1 presents the composition of the experimental diets.

TABLE 1 - Composition of the diets (per 100g).

\begin{tabular}{lcccc}
\hline \multicolumn{1}{c}{ Ingredients } & $\mathrm{C}$ & $\mathrm{PHVO}$ & $\mathrm{TF}$ & $\mathrm{O}$ \\
\hline Casein & 20 & 4 & 4 & 4 \\
Starch & 53 & 10.6 & 10.6 & 10.6 \\
Saccharose & 10 & 2 & 2 & 2 \\
Soy oil & 7 & 0 & 0 & 0 \\
Partially hydrogenated veg- & 0 & 80 & 0 & 0 \\
etable oil & & & & \\
Trans-free margarine & 0 & 0 & 80 & 0 \\
Enriched trans-free margarine & 0 & 0 & 0 & 80 \\
Fiber & 5 & 1 & 1 & 1 \\
Minerals & 3.5 & 0.7 & 0.7 & 0.7 \\
Vitamins & 1 & 0.2 & 0.2 & 0.2 \\
L-cystine & 0.3 & 0.06 & 0.06 & 0.06 \\
Choline & 0.25 & 0.05 & 0.05 & 0.05 \\
BHT mg & 1.4 & 0.28 & 0.28 & 0.28 \\
Energy per 100g/diet (kcal) & 397.2 & 786.8 & 786.8 & 786.8 \\
\hline *BHT - di-tert-butyl methyl phenol; C-Control group; NR - group without refeed- \\
$\begin{array}{l}\text { ing; PHVO - group receiving partially hydrogenated vegetable oil; TF - Trans- } \\
\text { free margarine group; O - group receiving margarine containing omega 3 and 6. }\end{array}$
\end{tabular}

The high-fat diets offered contained 93.4\% lipids, while the standard AIN-93 diet only contains 7\% lipids from soil oil. The composition of the oils and margarines used is listed in Table 2.

TABLE 2 - Percentage of fatty acids in the lipid sources used to prepare the diets.

\begin{tabular}{lcccc}
\hline Fatty acid & Soy oil & PHVO & Trans-free M & $\begin{array}{c}\text { Enriched } \\
\text { trans-free M }\end{array}$ \\
\hline $12: 0$ & ND & 0.03 & 5.15 & 5.14 \\
$14: 0$ & 0.07 & 0.12 & 2.15 & 1.89 \\
$16: 0$ & 10.64 & 14.60 & 31.09 & 12.30 \\
$16: 1$ & ND & 0.11 & 0.10 & 0.07 \\
$18: 0$ & 2.88 & 12.44 & 3.97 & 7.56 \\
$18: 1 n 9 \mathrm{c}$ & 27.07 & ND & 27.15 & 21.03 \\
$18: 1 n 9 t$ & 0.06 & 44.95 & ND & 0.04 \\
$18: 2 \mathrm{n} 6 \mathrm{c}$ & 52.03 & 23.35 & 24.80 & 45.35 \\
$18: 2 \mathrm{n} 6 \mathrm{t}$ & 0.22 & 0.13 & 1.39 & 0.31 \\
$18: 3 \mathrm{n} 3$ & 5.22 & 2.26 & 2.37 & 4.78 \\
$20: 5 \mathrm{n} 3$ & 0.40 & 0.42 & 0.09 & 0.19 \\
Others & 1.40 & 1.58 & 1.33 & 1.74 \\
\hline
\end{tabular}

PHVO - partially hydrogenated vegetable oil; Trans-free $\mathrm{M}$ - trans-free margarine; Enriched Trans-free M- trans-free margarine containing omega 3 and 6.
Thirty grams of diet were offered in individual stainless still containers and the amount consumed was determined before decapitation. The animals were weighed at the beginning of the experiment, after a 48 hour fast and immediately before sacrifice. Liver and blood were collected for biochemical determinations.

\section{Biochemical analysis}

Total hepatic fat was measured by the method of Bligh and Dyer ${ }^{15}$ in a $500 \mathrm{mg}$ liver aliquot.

The total fatty acids of liver and experimental oil were determined by gas chromatography (Shimadzu Europe, Duisburg, Germany) using an instrument fitted with a polar SGE International (SGE Europe Ltd., United Kingdom) BPX70 column (30 m, $0.25 \mathrm{~mm}$ I.D., film thickness $0.25 \mathrm{~mm}$ ). Helium was used as carrier gas and make-up air. Synthetic air and hydrogen were used for flame ionization detection at $280^{\circ} \mathrm{C}$. Injections were made in the split mode. Fatty acids were determined by gas chromatography using an external standard (Supelco 37 component FAME Mix). Tissue fatty acids were determined by a direct transesterification method adapted from Lewis et al. ${ }^{16}$. After the determination, the peroxidability index (PI) was calculated to determine the degree of unsaturation of the hepatic fatty acids according to the method of Pamplona et $a l^{17}: \mathrm{PI}=(\%$ monoenoic acids $\times 0.025)+(\%$ dienoic acids $\mathrm{x} 1)$ $+(\%$ trienoic acids $\times 2)+(\%$ tetraenoic acids $\mathrm{x} 4)+($ pentaenoic acids x 6) $+($ hexaenoic acid x 8 ).

Lipid peroxidation was measured in the liver by the determination of malondialdeide (MDA) according to the method of Gerard-Monnier et al. ${ }^{18}$ and catalase activity was assessed according to the technique proposed by Aebi ${ }^{19}$ and expressed as $\mathrm{U}$ $(\mathrm{mol} / \mathrm{min}) / \mathrm{mg}$ protein.

\section{Statistical analysis}

Data are reported as mean \pm standard deviation. The groups were compared by one-way analysis of variance followed by the Tukey post-test. The level of significance adopted was $\mathrm{p}<0.05$.

\section{Results}

The animals of the refed groups differed in growth from group $\mathrm{C}(\mathrm{p}<0.01$ for $\mathrm{PHVO}, \mathrm{p}<0.001$ for $\mathrm{TF}$ and $\mathrm{O})$. The NR group showed a lower mean body weight than group $C$, although the difference was not significant $(p>0.05)$. These data are presented in Table 3. 
TABLE 3 - Comparison of the general characteristics of the groups.

\begin{tabular}{lccccc}
\hline & $\mathrm{C}$ & $\mathrm{NR}$ & $\mathrm{PHVO}$ & $\mathrm{TF}$ & $\mathrm{O}$ \\
\hline \% Diet consumption & $58.33 \pm 11.89^{\mathrm{a}}$ & - & $56.33 \pm 30.12^{\mathrm{a}}$ & $87.33 \pm 4.44^{\mathrm{b}}$ & $86.00 \pm 9.27^{\mathrm{b}}$ \\
Final weight(g) & $269.6 \pm 12.70^{\mathrm{a}}$ & $275.4 \pm 8.66^{\mathrm{a}, \mathrm{b}}$ & $289.2 \pm 14.62^{\mathrm{b}, \mathrm{c}}$ & $304.2 \pm 7.10^{\mathrm{d}}$ & $303 \pm 10.94^{\mathrm{c}, \mathrm{d}}$ \\
Liver weight (g) & $13.34 \pm 2.15^{\mathrm{a}}$ & $8.24 \pm 0.60^{\mathrm{b}}$ & $10.17 \pm 1.77^{\mathrm{c}}$ & $11.28 \pm 0.70^{\mathrm{c}}$ & $11.21 \pm 0.76^{\mathrm{c}}$ \\
(\% Body weight) & $4.93 \pm 0.66^{\mathrm{a}}$ & $2.99 \pm 0.18^{\mathrm{b}}$ & $3.51 \pm 0.53^{\mathrm{c}}$ & $3.71 \pm 0.21^{\mathrm{c}}$ & $3.70 \pm 0.17^{\mathrm{c}}$ \\
\% Liver fat & $3.56 \pm 1.00^{\mathrm{a}}$ & $4.55 \pm 1.16^{\mathrm{a}, \mathrm{b}}$ & $7.93 \pm 2.99^{\mathrm{c}}$ & $6.62 \pm 1.90^{\mathrm{b}, \mathrm{c}}$ & $6.50 \pm 1.91^{\mathrm{b}, \mathrm{c}}$ \\
\hline
\end{tabular}

Data are reported as mean \pm SD. ${ }^{\text {a,b,c,d }}$ Mean values on the same line followed by different letters were significantly different $(\mathrm{p}<0.05$; ANOVA followed by the Tukey post test). C - control group; NR - group without refeeding; PHVO - group receiving partially hydrogenated fat; $\mathrm{TF}$ - trans-free margarine group; $\mathrm{O}$ group receiving margarine containing omega 3 and 6.

The offer of high-fat diets caused an increase in percent hepatic fat in groups $\mathrm{PHVO}, \mathrm{TF}$ and $\mathrm{O}$ compared to group $\mathrm{C}(\mathrm{p}<0.001$ for PHVO, $\mathrm{p}<0.01$ for TF and $\mathrm{p}<0.05$ for $\mathrm{O}$ ) and group PHVO also had higher mean values compared to group NR $(p<0.01)$. Liver weight was lower in the experimental groups compared to group $\mathrm{C}$ ( $p<0.001$ for NR and PHVO and $\mathrm{p}<0.01$ for TF and O) and group NR differed from all others $(\mathrm{p}<0.001$ for $\mathrm{TF}$ and $\mathrm{O}$ and $\mathrm{p}<0.05$ for PHVO); the same was observed for the liver/total body weight ratio, with the experimental groups showing a lower ratio compared to group $\mathrm{C}(\mathrm{p}<0.001)$ and group NR also had a lower ratio than the remaining groups $(\mathrm{p}<0.01$ for $\mathrm{TF}$ and $\mathrm{O}$ and $\mathrm{p}<0.05$ for $\mathrm{PHVO})$.

The quantity of hepatic protein was lower in groups PHVO and $\mathrm{O}$ compared to group $\mathrm{C}$ ( $\mathrm{p}<0.05$ and $\mathrm{p}<0.01$, respectively).

Table 4 shows the saturated fatty acid (SFA) profile of hepatic tissue. There was a lower concentration of 16:0 in groups PHVO and $\mathrm{O}$ compared to groups $\mathrm{C}(\mathrm{p}<0.001)$, NR $(\mathrm{p}<0.01$ for $\mathrm{PHVO}$ and $\mathrm{p}<0.05$ for $\mathrm{O})$ and TF $(\mathrm{p}<0.001)$ and in group NR compared to group $\mathrm{C}(\mathrm{p}<0.01)$; Group TF had a higher mean compared to groups $\mathrm{C}(\mathrm{p}<0.01)$ and NR $(\mathrm{p}<0.001)$. Group NR had a greater amount of 18:0 compared to the remaining groups $(\mathrm{p}<0.001)$, and group TF had lower values compared to groups $\mathrm{C}(\mathrm{p}<0.01)$ and $\mathrm{O}(\mathrm{p}<0.01)$. The amount of saturated fatty acids was lower in groups $\mathrm{PHVO}$ and $\mathrm{O}$ compared to the remaining ones $(\mathrm{p}<0.001)$.

Table 5 shows the liver monounsaturated fatty acid (MUFA) profile. The trans fatty acid, 18:1n9t was incorporated only in the PHVO. The sum of MUFAs was lower in the NR $(\mathrm{p}<0.05)$.

TABLE 4 - Composition of hepatic saturated fatty acids (wt\%) as methyl esters.

\begin{tabular}{lccccc}
\hline Fatty acid & $\mathrm{C}$ & $\mathrm{NR}$ & $\mathrm{PHVO}$ & $\mathrm{TF}$ & $\mathrm{O}$ \\
\hline $14: 0$ & $0.30 \pm 0.08^{\mathrm{a}}$ & $0.25 \pm 0.03^{\mathrm{a}}$ & $0.30 \pm 0.05^{\mathrm{a}}$ & $0.50 \pm 0.10^{\mathrm{b}}$ & $0.48 \pm 0.05^{\mathrm{b}}$ \\
$16: 0$ & $21.70 \pm 1.35^{\mathrm{a}}$ & $19.38 \pm 0.99^{\mathrm{b}}$ & $17.7 \pm 1.73^{\mathrm{c}}$ & $23.92 \pm 1.11^{\mathrm{d}}$ & $17.38 \pm 1.49^{\mathrm{c}}$ \\
$18: 0$ & $15.35 \pm 1.79^{\mathrm{a}}$ & $19.12 \pm 1.42^{\mathrm{b}}$ & $15.01 \pm 1.93^{\mathrm{a}, \mathrm{c}}$ & $13.25 \pm 1.17^{\mathrm{c}}$ & $15.79 \pm 0.52^{\mathrm{a}}$ \\
$24: 0$ & $1.13 \pm 0.24^{\mathrm{a}}$ & $1.12 \pm 0.18^{\mathrm{a}}$ & $0.98 \pm 0.12^{\mathrm{a}, \mathrm{b}}$ & $0.88 \pm 0.12^{\mathrm{b}}$ & $0.84 \pm 0.09^{\mathrm{b}}$ \\
SFA & $39.70 \pm 1.22^{\mathrm{a}}$ & $40.73 \pm 1.23^{\mathrm{a}}$ & $34.19 \pm 3.45^{\mathrm{b}}$ & $39.16 \pm 1.37^{\mathrm{a}}$ & $35.29 \pm 1.51^{\mathrm{b}}$ \\
\hline
\end{tabular}

Data are reported as mean \pm SD. a,b,c,d Mean values on the same line followed by different letters were significantly different ( $<<0.05$; ANOVA followed by the Tukey post test). C - control group; NR - group without refeeding; $\mathrm{PHVO}$ - group receiving partially hydrogenated fat; $\mathrm{TF}$ - trans-free margarine group; $\mathrm{O}$ - group receiving margarine containing omega 3 and 6; SFA - saturated fatty acid.

TABLE 5 - Composition of hepatic monounsaturated fatty acids (wt $\%)$ as methyl esters.

\begin{tabular}{|c|c|c|c|c|c|}
\hline Fatty acid & $\mathrm{C}$ & NR & PHVO & $\mathrm{TF}$ & $\mathrm{O}$ \\
\hline $16: 1$ & $1.42 \pm 0.99^{\mathrm{a}}$ & $0.70 \pm 0.22^{\mathrm{b}, \mathrm{c}}$ & $1.17 \pm 0.44^{\mathrm{a}, \mathrm{b}}$ & $0.17 \pm 0.04^{\mathrm{c}}$ & $0.24 \pm 0.12^{\mathrm{c}}$ \\
\hline $18: \ln 9 \mathrm{c}$ & $9.24 \pm 1.18^{\mathrm{a}, \mathrm{b}}$ & $6.22 \pm 0.85^{\mathrm{a}}$ & $14.24 \pm 5.34^{\mathrm{c}}$ & $13.62 \pm 1.13^{\mathrm{c}}$ & $9.98 \pm 0.57^{b}$ \\
\hline $18: \ln 9 t$ & $\mathrm{NDa}$ & Nda & $1.95 \pm 0.99^{\mathrm{b}}$ & $\mathrm{NDb}$ & $\mathrm{NDb}$ \\
\hline $20: \ln 9$ & $0.08 \pm 0.01^{\mathrm{a}, \mathrm{b}}$ & $0.06 \pm 0.01^{\mathrm{b}}$ & $0.11 \pm 0.04^{\mathrm{c}}$ & $0.10 \pm 0.02^{\mathrm{a}}$ & $0.11 \pm 0.02^{\mathrm{c}}$ \\
\hline $24: \ln 9$ & $0.089 \pm 0.018^{\mathrm{a}}$ & $0.076 \pm 0.014^{\mathrm{a}}$ & $0.048 \pm 0.017^{b}$ & $0.023 \pm 0.007^{\mathrm{c}}$ & $0.028 \pm 0.009^{c}$ \\
\hline MUFA & $10.87 \pm 2.03^{\mathrm{ab}}$ & $7.10 \pm 1.01^{\mathrm{b}}$ & $17.58 \pm 6.22^{\mathrm{c}}$ & $13.99 \pm 1.13^{\mathrm{ac}}$ & $10.40 \pm 0.63^{\mathrm{ab}}$ \\
\hline
\end{tabular}

Data are reported as mean \pm SD. a,b,c,d Mean values on the same line followed by different letters were significantly different ( $p<0.05$; ANOVA followed by the Tukey post test). C - control group; NR - group without refeeding; PHVO - group receiving partially hydrogenated fat; TF - trans-free margarine group; $\mathrm{O}$ - group receiving margarine containing omega 3 and 6; MUFA monounsaturated fatty acid. 
The liver polyunsaturated fatty acids (PUFA) are show in the Table 6. The sum of PUFAs are higher in the NR and O compared to $\mathrm{C}$ ( $\mathrm{p}<0.05$ for both), PHVO ( $<<0.05$ for both) and TF ( $\mathrm{p}<0.05$ for both).

The Table 7 shows the $\mathrm{n} 6 / \mathrm{n} 3$ ratio, which was higher in the NR and $\mathrm{O}$ group compared to $\mathrm{C}$ ( $\mathrm{p}<0.05$ for both), PHVO ( $\mathrm{p}<0.05$ for both) and TF ( $<<0.05$ for both). The peroxidability index (PI) was lower in the TF and O groups compared to C, NR and PHVO ( $<<0.05$ for all), and lower in the PHVO compared to NR and $\mathrm{C}$ ( $\mathrm{p}<0.05$ for both); the NR had higher PI compared to $\mathrm{C}(\mathrm{p}<0.05)$.

TABLE 6 - Composition of hepatic polyunsaturated fatty acids (wt $\%$ ) as methyl esters.

\begin{tabular}{|c|c|c|c|c|c|}
\hline Fatty acid & $\mathrm{C}$ & NR & PHVO & $\mathrm{TF}$ & $\mathrm{O}$ \\
\hline $18: 2 \mathrm{n} 6 \mathrm{c}$ & $23.62 \pm 2.19^{\mathrm{a}, \mathrm{b}}$ & $22.81 \pm 1.87^{\mathrm{a}}$ & $25.72 \pm 1.40^{\mathrm{b}}$ & $29.18 \pm 1.28^{c}$ & $35.94 \pm 1.48^{\mathrm{d}}$ \\
\hline $18: 2 \mathrm{n} 6 \mathrm{t}$ & $\mathrm{NDa}$ & Nda & $0.03 \pm 0.02^{b}$ & NDa & $\mathrm{NDa}$ \\
\hline $18: 3 n 6$ & $0.38 \pm 0.06^{\mathrm{a}, \mathrm{b}}$ & $0.31 \pm 0.09^{\mathrm{a}}$ & $0.36 \pm 0.19^{\mathrm{a}}$ & $0.43 \pm 0.06^{\mathrm{a}, \mathrm{b}}$ & $0.51 \pm 0.08^{b}$ \\
\hline $18: 3 n 3$ & $0.61 \pm 0.15^{\mathrm{a}}$ & $0.73 \pm 0.14^{\mathrm{a}}$ & $1.03 \pm 0.22^{b}$ & $1.37 \pm 0.16^{\mathrm{c}}$ & $2.21 \pm 0.21^{\mathrm{d}}$ \\
\hline $20: 3 n 6$ & $0.41 \pm 0.07^{\mathrm{a}}$ & $0.26 \pm 0.03^{b}$ & $0.19 \pm 0.03^{\mathrm{c}}$ & $0.26 \pm 0.04^{b}$ & $0.27 \pm 0.04^{b}$ \\
\hline $20: 3 n 3$ & $0.77 \pm 0.13^{\mathrm{a}}$ & $0.37 \pm 0.07^{\mathrm{b}}$ & $0.45 \pm 0.13^{b}$ & $0.82 \pm 0.13^{\mathrm{a}}$ & $0.65 \pm 0.14^{\mathrm{a}}$ \\
\hline $20: 4 n 6$ & $19.31 \pm 1.08^{\mathrm{a}}$ & $23.39 \pm 1.76^{\mathrm{b}}$ & $16.93 \pm 3.78^{\mathrm{a}}$ & $11.98 \pm 1.36^{\mathrm{c}}$ & $11.94 \pm 1.05^{\mathrm{c}}$ \\
\hline $20: 5 n 3$ & $0.47 \pm 0.07^{\mathrm{a}, \mathrm{b}, \mathrm{c}}$ & $0.48 \pm 0.06^{\mathrm{a}, \mathrm{b}, \mathrm{c}}$ & $0.50 \pm 0.07^{b}$ & $0.41 \pm 0.05^{\mathrm{c}}$ & $0.50 \pm 0.06^{\mathrm{b}}$ \\
\hline
\end{tabular}

Data are reported as mean \pm SD. ${ }^{\text {a,b,c,d }}$ Mean values on the same line followed by different letters were significantly different ( $p<0.05$; ANOVA followed by the Tukey post test). C - control group; NR - group without refeeding; PHVO - group receiving partially hydrogenated fat; TF - trans-free margarine group; $\mathrm{O}$ - group receiving margarine containing omega 3 and 6; PUFA polyunsaturated fatty acid.

TABLE 7 - Ratios of $n-6 / n-3$, conversion of fatty acids and peroxidability index.

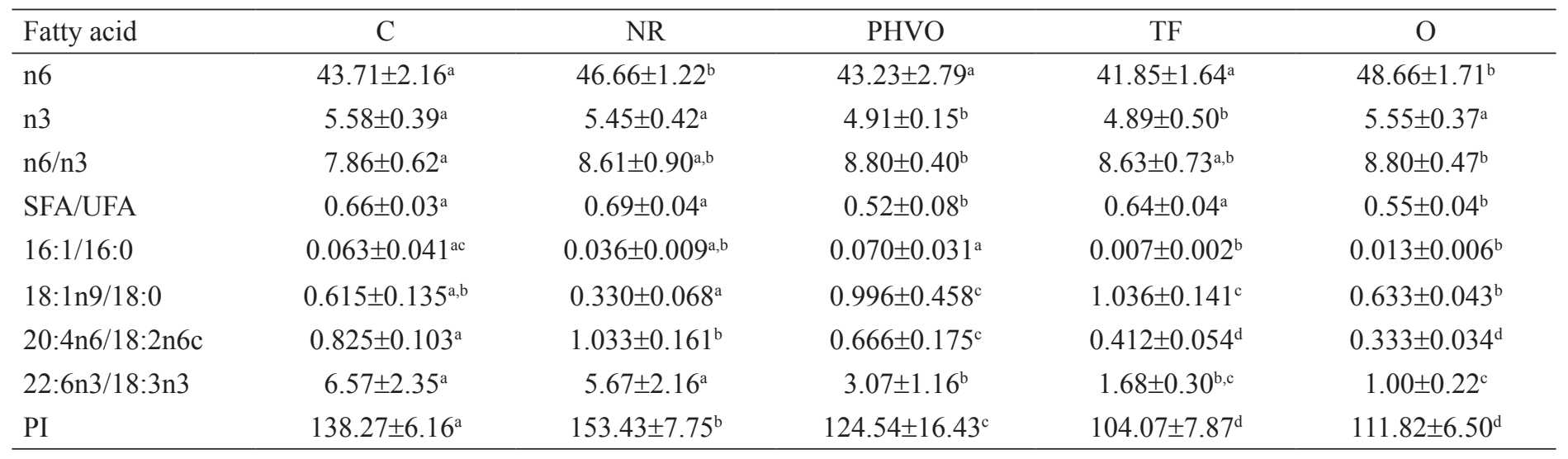

Data are reported as mean \pm SD. a,b,c,d Mean values on the same line followed by different letters were significantly different ( $<<0.05$; ANOVA followed by the Tukey post test). C - control group; NR - group without refeeding; PHVO - group receiving partially hydrogenated fat; TF - trans-free margarine group; O - group receiving margarine containing omega 3 and 6; n-6 polyunsaturated omega-6 fatty acids; n-3 polyunsaturated omega-3 fatty acids; PI - peroxidability index. 
The groups receiving high-fat diets presented elevation of MDA levels about double that of group $\mathrm{C}(\mathrm{p}<0.001$ for PHVO and $\mathrm{p}<0.01$ for $\mathrm{TF}$ and $\mathrm{O}$ ), as show in Figure 1 .

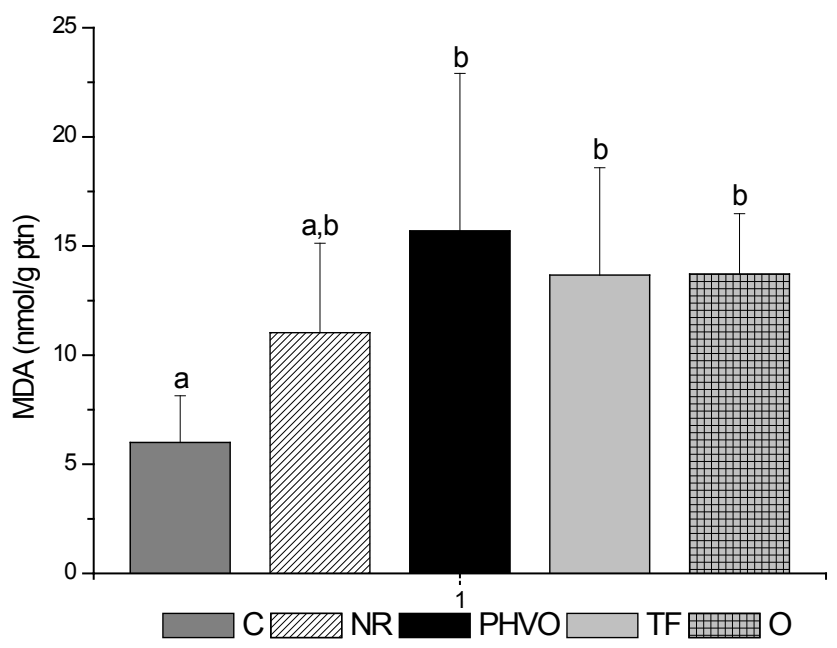

FIGURE 1 - Hepatic malondialdehyde (MDA). The wide vertical bars represent the mean values, and the fine bars represent the standard deviation. a,b Mean values with different letters in the same bar were significantly different $(\mathrm{p}<0.05$; ANOVA followed by the Tukey post test). C - control group; NR - group without refeeding; PHVO - group receiving partially hydrogenated fat; $\mathrm{TF}$ - trans-free margarine group; $\mathrm{O}$ - group receiving margarine containing omega 3 and 6.

Figure 2 shows the activity of hepatic catalase, an antioxidant enzyme, was higher in groups $\mathrm{TF}$ and $\mathrm{O}$ compared to group $\mathrm{C}$ ( $\mathrm{p}<0.05$ for both).

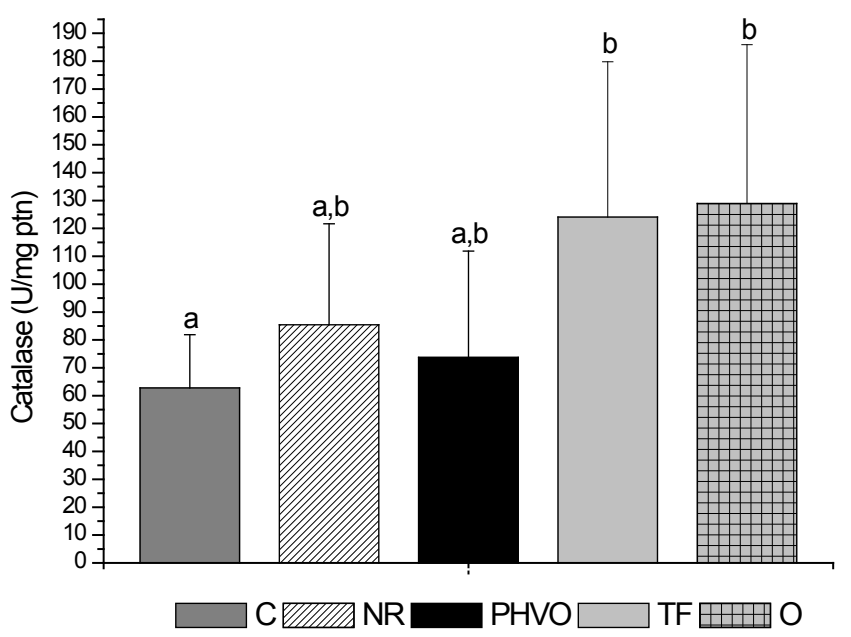

FIGURE 2 - Hepatic catalase activity. The wide vertical bars represent the mean values, and the fine bars represent the standard deviation. a,b Mean values with different letters in the same bar were significantly different $(\mathrm{p}<0.05$; ANOVA followed by the Tukey post test.. C - control group; NR - group without refeeding; $\mathrm{PHVO}$ - group receiving partially hydrogenated fat; $\mathrm{TF}$ - trans-free margarine group; $\mathrm{O}$ - group receiving margarine containing omega 3 and 6.

\section{Discussion}

The offer of high-fat diets to rats represents an experimental model for the study of diseases such as NAFLD and metabolic syndrome $\mathrm{e}^{20-22}$. The effects of trans fatty acids on the increase in LDL cholesterol levels and the decrease of HDL cholesterol levels are also well known ${ }^{23}$. In addition, these fatty acids are related to an increased incidence of obesity and diabetes mellitus type $2^{24}$.

The greater palatability of the diets offered to groups TF and $\mathrm{O}$ justifies the greater food consumption by these animals. Consequently, these groups also had a greater final body weight.

The percentage of hepatic fat shows that animals refed with a fat-rich diet presented increased lipid amounts in the liver. Refeeding with a high-fat diet after a prolonged fast maintains an elevated concentration of free fatty acids ${ }^{25}$, which will be taken up by the liver and will participate in $\beta$-oxidation during fasting.

The reduction of hepatic volume in the NR group represents an adaptive metabolic change in response to the period of food deprivation. The gastrointestinal tract has a high metabolic rate and therefore the reduction in volume of these organs represents a way of saving energy and is one of the morphological changes due to food deprivation ${ }^{26}$.

Glucose and glycogen stores are initially utilized during fasting and, with the increase in the time of deprivation, there is consumption of triglycerides and release of free fatty acids and glycerol from adipose tissue and proteins, since amino acids will be used for gluconeogenesis ${ }^{26}$.

Trans fatty acids are absorbed at a high rate, with 18:1t having a $95 \%$ coefficient of absorption, and they are also oxidized at rates similar to those of cis fatty acids ${ }^{27}$. Although fatty acids are efficiently absorbed, refeeding with a diet rich in $18: \ln 9 \mathrm{t}$ resulted in the incorporation of about $2 \%$ of this fatty acid into the liver of Wistar rats. The offer of a diet containing partially hydrogenated vegetable oil for longer periods of time results in increased amounts of this fatty acid in the hepatocytes ${ }^{28,29}$.

The groups refed with trans-free margarine and enriched margarine showed a reduction of the essential long-chain fatty acids 20:4n6 and 22:6n3. Although enriched margarine contained greater quantities of essential fatty acids, especially in the form of $18: 2 \mathrm{n} 6$ and $18: 3 \mathrm{n} 3$, these fatty acids were not efficiently elongated or desaturated during the refeeding period, as demonstrated by the lower concentrations of 20:4n 6 and $22: 6 \mathrm{n} 3$ and by the 20:4n6/18:2n6 and 22:6n3/18:3n3 ratios. Neither margarine contained significant amounts of trans fatty acids.

The reduced rates of conversion of saturated to monunsaturated fatty acids in NR group demonstrates the 
reduced activity of the enzymes involved in desaturation and elongation. Stearoyl-CoA desaturase-1 (SCD-1) is the enzyme responsible for the conversion of $16: 0$ to $16: 1$ and of 18:0 to18:1. The hepatic expression of this enzyme is reduced under fasting conditions and does not increase with refeeding with a high-fat diet ${ }^{25}$. Thus, it is possible to conclude that the lower activity of this enzyme caused a low 16:1/16:0 ratio in groups NR, TF and $\mathrm{O}$.

Although SCD-1 activity was reduced in the NR group, this group presented the highest 20:4n6 values and the highest 20:4n6/18:2n6 ratio, indicating that arachidonic acid is spared during prolonged fasting, as also are most PUFAs, since this group showed reduction of SFAs and MUFAs.

The analysis of lipid peroxidation based on the determination of MDA, a product of this process, demonstrated that the animals refed with high-fat diets suffered greater lipoperoxidation. The pro-oxidative environment caused by excess dietary lipids favors the progression of NAFLD to $\mathrm{NASH}$, corresponding to the second step in the development of the disease. Elevated hepatic MDA concentrations and reduced superoxide dismutase activity indicate an environment favorable to lipid peroxidation and to the consequent development of $\mathrm{NASH}^{30}$. The products of lipid peroxidation are inflammatory mediators and may activate stellate cells, stimulating collagen synthesis and favoring the progression to tissue fibrosis ${ }^{31}$, with progression from NASH to cirrhosis of the liver. Thus, it is of fundamental importance to look at antioxidants as essential tools in the prevention of NASH.

Catalase is an enzymatic antioxidant present in the peroxisomes which acts in the decomposition of hydrogen peroxide to water molecules and to molecular oxygen, preventing the accumulation of this toxic component ${ }^{32}$. Hydrogen peroxide $\left(\mathrm{H}_{2} \mathrm{O}_{2}\right)$ is a reactive oxygen species that acts like all other free radicals in the peroxidation of lipid membranes and causes cell damage. Thus, its concentrations increased in proportion of the production of $\mathrm{H}_{2} \mathrm{O}_{2}$. The increased values observed here in the groups refed with trans-free margarine and margarine enriched with $\omega-3, \omega-6$ and monounsaturated show that in these groups there was a greater formation of $\mathrm{H}_{2} \mathrm{O}_{2}$, indicating that these lipid sources activated this pathway.

Catalase is mainly present in the peroxisomes, in which long-chain fatty acids are oxidized. The increased activity of this enzyme suggests a greater oxidation of these fatty acids. The higher activity of this enzyme is also linked to a higher expression of the transcription factor PPAR- $\gamma$ which is associated with the development of hepatic steatosis ${ }^{33}$.

\section{Conclusions}

The consumption of high-fat diets after prolonged food restriction favors oxidative imbalance in hepatic tissue, as demonstrated by the increased concentrations of lipid peroxidation metabolites and consumption of antioxidant substances. Fasting also results in oxidative stress, although with lower intensity.

\section{References}

1. Targher G, Byrne CD. Clinical review: nonalcoholic fatty liver disease: a novel cardiometabolic risk factor for type 2 diabetes and its complications. J Clin Endocrinol Metab. 2013;98(2):483-95.

2. Day CP, James OF. Steatohepatitis: a tale of two "hits"? Gastroenterology. 1998;114(4):842-5.

3. Utzschneider KM, Kahn SE. Review: the role of insulin resistance in nonalcoholic fatty liver disease. J Clin Endocrinol Metab. 2006;91(12):4753-61.

4. Portincasa P, Grattagliano I, Palmieri VO, Palasciano G. The emerging problem of nonalcoholic steatohepatitis (NASH). Rom J Gastroenterol. 2005;14(1):43-51.

5. Monteleone P, Brambilla F, Bortolotti F, Maj M. Serotonergic dysfunction across the eating disorders: relationship to eating behaviour, purging behaviour, nutritional status and general psychopathology. Psychol Med. 2000;30(5):1099-110.

6. Shatenstein B, Ghadirian P, Lambert J. Influence of the Jewish Religion and Jewish Dietary Laws (kashruth) on family food habits in an ultra-orthodox population in Montreal. Ecol Food Nutr. 1992;31:27-44.

7. M'Guil M, Ragala MA, El Guessabi L, Fellat S, Chraibi A, Chabraoui L, Israili ZH, Lyoussi B. Is Ramadan fasting safe in type 2 diabetic patients in view of the lack of significant effect of fasting on clinical and biochemical parameters, blood pressure, and glycemic control? Clin Exp Hypertens. 2008;30(5):339-57.

8. van Ginneken V, Verhey E, Poelmann R, Ramakers R, van Dijk KW, Ham L, Voshol P, Havekes L, Van Eck M, van der Greef J. Metabolomics (liver and blood profiling) in a mouse model in response to fasting: a study of hepatic steatosis. Biochim Biophys Acta. 2007;1771(10):1263-70.

9. Larter CZ, Yeh MM. Animal models of NASH: getting both pathology and metabolic context right. J Gastroenterol Hepatol. 2008;23(11):1635-48.

10. Zelber-Sagi S, Nitzan-Kaluski D, Goldsmith R, Webb M, Blendis L, Halpern Z, Oren R. Long term nutritional intake and the risk for non-alcoholic fatty liver disease (NAFLD): a population based study. J Hepatol. 2007;47(5):711-7.

11. Gentile CL, Pagliassotti MJ. The role of fatty acids in the development and progression of nonalcoholic fatty liver disease. $\mathrm{J}$ Nutr Biochem. 2008;19(9):567-76.

12. Videla LA, Rodrigo R, Araya J, Poniachik J. Oxidative stress and depletion of hepatic long-chain polyunsaturated fatty acids may contribute to nonalcoholic fatty liver disease. Free Radic Biol Med. 2004;37(9):1499-507.

13. The Guide for the Care and Use of Laboratory Animals. National Institutes of Health, ed. N.A.o. Sciences; 1985.

14. Reeves PG, Nielsen FH, Fahey GC, Jr. AIN-93 purified diets for laboratory rodents: final report of the American Institute of Nutrition ad hoc writing committee on the reformulation of the AIN-76A rodent diet. J Nutr. 1993;123(11):1939-51.

15. Bligh EG. Dyer WJ, A rapid method of total lipid extraction and 
purification. Can J Biochem Physiol. 1959;37(8):911-7.

16. Lewis T, Nichols PD, McMeekin TA. Evaluation of extraction methods for recovery of fatty acids from lipid-producing microheterotrophs. J Microbiol Methods. 2000;43(2):107-16.

17. Pamplona R, Portero-Otin M, Riba D, Ruiz C, Prat J, Bellmunt MJ, Barja G. Mitochondrial membrane peroxidizability index is inversely related to maximum life span in mammals. J Lipid Res. 1998;39(10):1989-94.

18. Gerard-Monnier D, Erdelmeier I, Regnard K, Moze-Henry N, Yadan JC, Chaudiere J. Reactions of 1-methyl-2-phenylindole with malondialdehyde and 4-hydroxyalkenals. Analytical applications to a colorimetric assay of lipid peroxidation. Chem Res Toxicol. 1998;11(10):1176-83.

19. Aebi H. Catalase in vitro. Methods Enzymol. 1984;105:121-6.

20. Varela-Rey M, Embade N, Ariz U, Lu SC, Mato JM, Martinez-Chantar ML. Non-alcoholic steatohepatitis and animal models: understanding the human disease. Int J Biochem Cell Biol. 2009;41(5):969-76.

21. Leonardi DS, Feres MB, Portari GV, Zanuto ME, Zucoloto S, Jordao AA. Low-carbohydrate and high-fat diets on the promotion of hepatic steatosis in rats. Exp Clin Endocrinol Diabetes. 2010;118(10):724-9.

22. Picchi MG, Mattos AM, Barbosa MR, Duarte CP, Gandini Mde A, Portari GV, Jordao AA. A high-fat diet as a model of fatty liver disease in rats. Acta Cir Bras. 2011;26 Suppl 2:25-30.

23. Mensink RP, Katan MB. Effect of dietary trans fatty acids on highdensity and low-density lipoprotein cholesterol levels in healthy subjects. N Eng1 J Med. 1990;323(7):439-45.

24. Dorfman SE, Laurent D, Gounarides JS, Li X, Mullarkey TL, Rocheford EC, Sari-Sarraf F, Hirsch EA, Hughes TE, Commerford SR. Metabolic implications of dietary trans-fatty acids. Obesity (Silver Spring). 2009;17(6):1200-7.

25. Sanchez J, Palou A, Pico C. Response to carbohydrate and fat refeeding in the expression of genes involved in nutrient partitioning and metabolism: striking effects on fibroblast growth factor-21 induction. Endocrinology. 2009;150(12):5341-50.

26. Wang T, Hung CC, Randall DJ. The comparative physiology of food deprivation: from feast to famine. Annu Rev Physiol. 2006;68:223-51.

27. Emken EA, Rohwedder WK, Adlof RO, DeJarlais WJ, Gulley RM. Absorption and distribution of deuterium-labeled trans- and cis-11octadecenoic acid in human plasma and lipoprotein lipids. Lipids. 1986;21(9): 589-95.

28. Jeyakumar SM, Prashant A, Rani KS, Laxmi R, Vani A, Kumar PU, Vajreswari A. Chronic consumption of trans-fat-rich diet increases hepatic cholesterol levels and impairs muscle insulin sensitivity without leading to hepatic steatosis and hypertriglyceridemia in female fischer rats. Ann Nutr Metab. 2011;58(4):272-80.
29. Sabarense CM, Mancini Filho J. Efeito da gordura vegetal parcialmente hidrogenada sobre a incorporação de ácidos graxos trans em tecidos de ratos. Rev Nutr. 2003;16(4):399-407.

30. Zou Y, Li J, Lu C, Wang J, Ge J, Huang Y, Zhang L, Wang Y. Highfat emulsion-induced rat model of nonalcoholic steatohepatitis. Life Sci. 2006;79(11):1100-7.

31. Das KS, Balakrishnan V, Mukherjee S, Vasudevan DM. Evaluation of blood oxidative stress-related parameters in alcoholic liver disease and non-alcoholic fatty liver disease. Scand J Clin Lab Invest. 2008;68(4):323-34.

32. Valko M, Rhodes CJ, Moncol J, Izakovic M, Mazur M. Free radicals, metals and antioxidants in oxidative stress-induced cancer. Chem Biol Interact. 2006;160(1):1-40.

33. Girnun GD, Domann FE, Moore SA, Robbins ME. Identification of a functional peroxisome proliferator-activated receptor response element in the rat catalase promoter. Mol Endocrinol. 2002;16(12):2793-801.

\section{Correspondence:}

Alceu Afonso Jordão

Faculdade de Medicina de Ribeirão Preto

Laboratório de Nutrição e Metabolismo - Anexo A

Avenida Bandeirantes, 3900

14048-900 Ribeirão Preto - SP Brasil

Tel/Fax: (55 16)3602-4564

alceu@fmrp.usp.br

Received: Nov 14, 2013

Review: Jan 15, 2014

Accepted: Feb 18, 2014

Conflict of interest: none

Financial sources: National Council for Scientific and Technological Development $(\mathrm{CNPq})$ and Sao Paulo Research Foundation (FAPESP$\left.-n^{\circ} 2010 / 00408-1\right)$

${ }^{1}$ Research performed at Laboratory of Nutrition and Metabolism, Department of Internal Medicine, Faculty of Medicine of Ribeirao Preto-University of Sao Paulo (FMRP-USP), Brazil. Postgraduate Program in Internal Medicine, FMRP-USP. Tutor: Alceu Afonso Jordão. 